\title{
Cloning Vectors Derived from Plasmids and Phage of Bacillus
}

\author{
JÜRGEN KREFT* AND COLIN Hughes*
}

1 Introduction . . . . . . . . . . . . . . 1

2 Development and Use of Vector Plasmids c . . . . . . . . . . . . . . . 2

2.1 Vectors Capable of Replication Only in B. subtilis . . . . . . . . . . . . . 2

2.2 Hybrid Vectors Capable of Replication in E. coli and B. subtilis . . . . . . . . . . 6

2.3 Transformation . . . . . . . . . . . . . . . . . . . . . . . . 8

2.4 Stability of Vector Plasmids . . . . . . . . . . . . . . . . . . . . 9

2.5 Clone Analysis . . . . . . . . . . . . . . . . . . . . . . . . 10

3 Use of Bacteriophage Vectors . . . . . . . . . . . . . . . . . . . 10

4 Molecular Cloning with Plasmid Vectors . . . . . . . . . . . . . . . 11

5 Conclusions . . . . . . . . . . . . . . . . . . . . . . . . . 14

References . . . . . . . . . . . . . . 15

\section{Introduction}

Bacillus subtilis is a well-characterized, gram-positive, non-pathogenic, spore-forming soil bacterium which produces a wide array of extracellular enzymes (for reviews see Young 1980; Priest 1977; Henner and Hoch 1980). The development of molecular cloning systems within this organism will not only greatly assist biochemical and genetic studies but should play a fundamental role in the further development of biotechnological processes based on the Bacilli.

As described by Ehrlich (this volume), following the realization that antibiotic resistance plasmids from Staphylococcus aureus could be transformed into B. subtilis (Ehrlich 1977), much effort has been devoted to developing $S$. aureus plasmid cloning vectors for the Bacilli. In this review we will describe the current status of vectors constructed from plasmids and phage indigenous to the Bacilli.

In the wake of the development of recombinant DNA techniques in E. coli, studies of Bacillus plasmids gave way to searches aimed at isolating potential cloning vectors. Extrachromosomal DNA in Bacillus was first demonstrated in B. megaterium and since then many reports have been made of plasmids in this species (Carlton and Smith 1974; Rostas et a1. 1980), B. subtilis (Lovett and Bramucci 1975; Tanaka and Koshikawa 1977; Bernhard et al. 1978; Uozumi et al. 1980), and B. pumilus (Lovett et al. 1976).

\footnotetext{
* Institut für Genetik und Mikrobiologie der Universität, Röntgenring 11, D-8700 Würzburg, West Germany
} 
2 Jürgen Kreft and Colin Hughes

Table 1. Bacillus plasmids developed as cloning vehicles

\begin{tabular}{|c|c|c|c|c|c|c|}
\hline Plasmid & Source & $\begin{array}{l}\text { Mol. wt. } \\
\left(\mathrm{x} 10^{-6}\right)\end{array}$ & $\begin{array}{l}\text { Copy } \\
\text { number }\end{array}$ & $\begin{array}{l}\text { Restriction } \\
\text { sites }\end{array}$ & Marker & Reference \\
\hline$p L S 28$ & $\begin{array}{l}\text { B. subtilis } \\
\text { (natto) }\end{array}$ & 4.1 & 5 & $\begin{array}{l}E c o \mathrm{RI}(2), \operatorname{BamHI}(1), \\
H i n \mathrm{dIII}(5)\end{array}$ & - & $\begin{array}{l}\text { Tanaka and } \\
\text { Koshikawa } 1977\end{array}$ \\
\hline$p B S 1$ & B. subtilis & 5.5 & 6 & $\begin{array}{l}E c o \mathrm{RI}(1), \operatorname{BamHI}(1), \\
\operatorname{SaII}(1), \operatorname{Pst}(3) \\
\text { HindIII(6) }\end{array}$ & - & $\begin{array}{l}\text { Bernhard et al. } \\
1978\end{array}$ \\
\hline$p B C 16$ & B. cereus & 3.0 & 20 & $E c o \mathrm{RI}(2)$, BamHI(1) & $\mathrm{Tc}^{\mathrm{R}}$ & $\begin{array}{l}\text { Bernhard et al. } \\
1978\end{array}$ \\
\hline$p A B 124$ & $\begin{array}{l}\text { B. stearo- } \\
\text { thermophilus }\end{array}$ & 2.9 & $?$ & $\begin{array}{l}\text { EcoRI(3), HindIII(2), } \\
\text { single sites for } B s t \mathrm{EII}, \\
\text { CauI, HpaI, XbaI }\end{array}$ & $T c^{R}$ & $\begin{array}{l}\text { Bingham et al. } \\
1979\end{array}$ \\
\hline
\end{tabular}

Numbers in parentheses indicate the number of restriction sites for this enzyme

However, the majority of these plasmids, in most cases isolated from culture collection strains, lack readily identifiable markers and are thus not of immediate use as cloning vehicles. Nevertheless two such cryptic plasmids, $p B S 1$ and $p L S 28$, have been developed further. Examination of environmental isolates has proved more successful. Bernhard et al. (1978) isolated the tetracycline resistance $\left(\mathrm{Tc}^{\mathrm{R}}\right)$ plasmid $p B C 16$ from a strain of $B$. cereus found in soil, and the antibiotic-resistant thermophiles discovered in river sludge and silage yielded the two $\mathrm{Tc}^{\mathrm{R}}$ plasmids $p A B 124$ and $p A B 128$ (Bingham et al. 1979).

The following section describes the development of some of these plasmids (Table 1) as cloning vehicles.

\section{Development and Use of Vector Plasmids}

\subsection{Vectors Capable of Replication Only in B. subtilis}

The tetracycline resistance plasmid $p B C 16$ isolated from $B$. cereus can be transformed into B. subtilis (Bernhard et al. 1978) in which it replicates quite stably with no detectable segregation after more than 100 generations without selective pressure. It contains two $E c o R I$ sites and in order to determine if these sites were within the tetracycline resistance gene(s) $p B C 16$ was partially and completely digested with $E c o$ RI and ligated with $E c o$ RI linearized $p B S 1$, a cryptic plasmid isolated from $B$. subtilis.

None of the $\mathrm{Tc}^{\mathrm{R}}$ colonies obtained after transformation of competent cells of $B$. subtilis 168 with the ligated mixture contained a complete hybrid of the two parental plasmids but several derivatives were isolated (Fig. 1), $p B C 16-1, p B S 161$, and $p B S 161-1$ being of particular interest (Kreft et al. 1978). The plasmid $p B C 16-1$ is the circularized large EcoRI fragment (mol. wt. $1.8 \times 10^{6}$ ) of $p B C 16$ which obviously carries both the replication functions and the tetracycline resistance determinant.

$p B S 161$ and $p B S 162$ have been found together in a large number of tetracycline-resistant colonies, the former plasmid alone carrying a $\mathrm{Tc}^{\mathrm{R}}$ determinant.

Recircularization in vitro of the largest HindIII fragment of $p B S 161$ yielded $p B S 161-1$, 


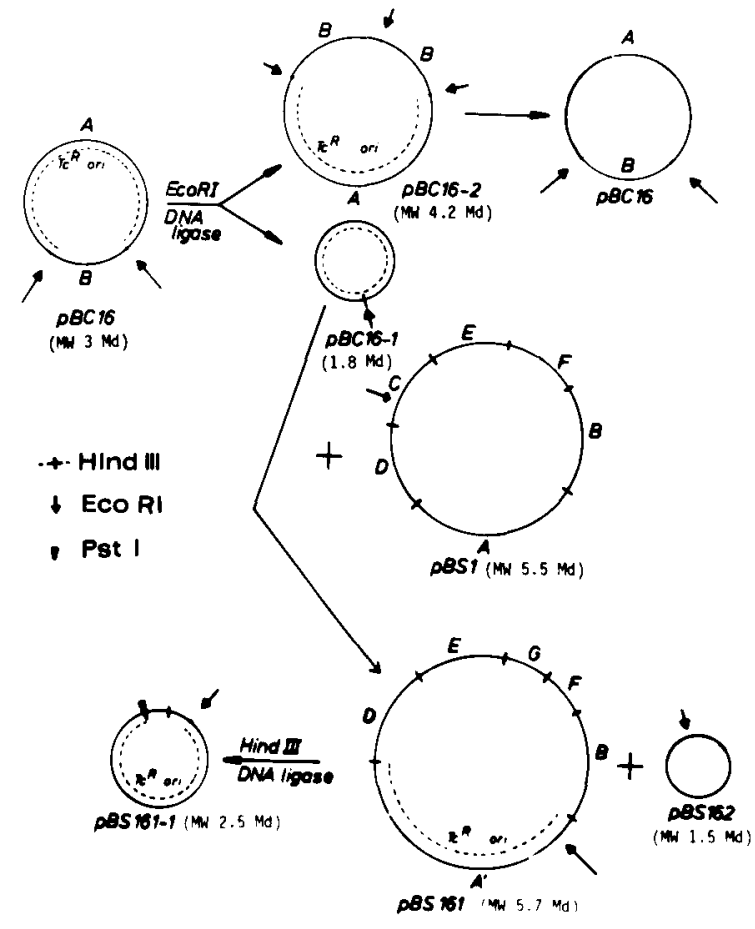

Fig. 1. Genealogy of Bacillus plasmids derived from $p B C 16$ and $p B S 1$. With the exception of $p B S 161-1$ only the restriction sites for EcoRI and HindIII are shown

a small $\mathrm{Tc}^{\mathrm{R}}$ plasmid (mol. wt. $2.5 \times 10^{6}$ ) with a high copy number (ca. 20), and single sites for HindIII, EcoRI, and PstI, none of which lies within the replication region or the tetracycline resistance determinant.

The recombinant plasmid RSF2124-B. leu (Nagahari and Sakaguchi 1978), contains the leucine $\mathrm{A}, \mathrm{B}$, and $\mathrm{C}$ genes of $B$. subtilis and can transform not only leu- $E$. colibut also $B$. subtilis to prototrophy. This plasmid is able to replicate only in E. coli. After digestion with EcoRI, ligation to EcoRI-cleaved B. subtilis (natto) plasmid $p L S 28$ (Table 1), and transformation of $B$. subtilis $\mathrm{RM} 125$ (leu ${ }^{-}$, recE4), leu+ transformants yielded two recombinant plasmids $p L S 101$ (mol. wt. $6.5 \times 10^{6}$ ) and $p L S 102$ (mol. wt. $10.7 \times 10^{6}$ ). After subcultivation of these clones slowly growing colonies have been observed containing only the plasmid $p L S 103$, which is indistinguishable from $p L S 101$ (Fig. 2).

Insertion of foreign DNA into the single BamHI site inactivates leuA but not leuC, which can thus be used as a marker (Tanaka and Sakaguchi 1978). A derivative of $p L S 103$ termed $p L L 10$, has only one $E c o$ RI site and complements leuA and $l e u \mathrm{~B}$ but not, in contrast to $p L S 103$, leuC. In order to see whether DNA insertion into the remaining $E c o \mathrm{RI}$ site inactivated the $l e u$ function and also to introduce another marker, an $E c o$ RI fragment carrying a $B$. subtilis 168 trimethoprim resistance determinant was recloned from $p B R 322-\mathrm{Tmp}^{\mathrm{R}}$ into $p L L 10$ and transformed into B. subtilis $\mathrm{ML112}$. leu ${ }^{+} \mathrm{Tmp}^{\mathrm{R}}$ clones yielded $p T L 10$ (Fig. 3), a plasmid of mol. wt. $9.4 \times 10^{6}$ giving two fragments of $5.7 \times 10^{6}$ and $3.7 \times 10^{6}$ after EcoRI digestion. The latter fragment could convert B. subtilis to $\mathrm{Tmp}^{\mathrm{R}}$ when inserted in both orientations, indicating its retention of the promoter (Tanaka and Kawano 1980). 


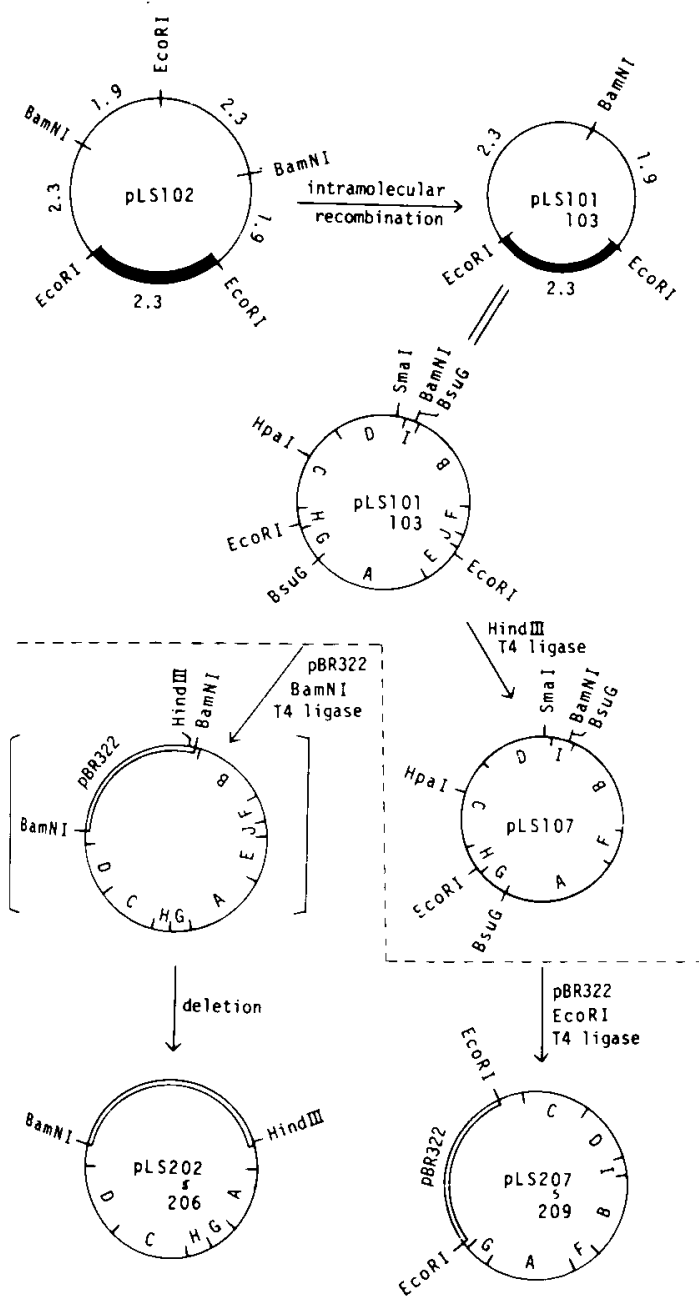

Fig. 2. Structure of constructed plasmids $p L S 101$ etc. Numbers denote the molecular weights $\left(\times 10^{-6}\right)$ of the DNA fragments. The thick and thin lines indicate the vector and the DNA segments containing the leucine gene respectively. Cleavage sites of EcoRI, BamNI, SmaI, and BsuG are shown inside the circles and those of HindIII outside. Courtesy of T. Tanaka and K. Sakaguchi

In order to reduce both the size and number of $E c o$ RI and $B g I I$ sites on $p T L 10$, the derivative $p T L 12$ has been constructed (Fig. 3); a leu ${ }^{+}$Tmp $^{\mathrm{R}}$ plasmid of mol. wt. $6.4 \times 10^{6}$ carrying single sites for $E c o \mathrm{RI}, B g I \mathrm{I}, \mathrm{BamHI}$, and $X m a \mathrm{I}$. leu inactivation occurs following insertion at the BamHI and $X m a I$ sites, and $B a m H I$ cleavage leaves a cohesive end (GATC), making possible the use of $B g I I I, B c l I$, and $M b o I$, which also leave this sequence. The presence of $\mathrm{Tmp}^{\mathrm{R}}$ as a marker allows direct selection of transformants.

The $\mathrm{Tc}^{\mathrm{R}}$ plasmid $p A B 124$ isolated from $B$. stearothermophilus has three $E c o \mathrm{RI}$ sites (Table 1). The circularized EcoRI-A fragment (pAB224) (Bingham et al. 1980) is capable of autonomous replication and carries the tetracycline resistance determinant. It contains single sites for seven restriction enzymes, three of which produce cohesive termini. $p A B 524$ has only one $E c o$ RI fragment of $p A B 124$ deleted (Fig. 4). Table 2 summarizes the properties of the plasmids described in this section. With the exception of $p T L 10$ and $p T L 12$, all these plasmids carry only one easily detectable genetic marker and do not allow 
Table 2. Vectors derived from plasmids listed in Table 1

\begin{tabular}{|c|c|c|c|c|}
\hline Vector & Source & $\begin{array}{l}\text { Mol. wt. } \\
\left(\mathrm{x} 10^{-6}\right)\end{array}$ & Single restriction sites & Markers \\
\hline$p B C 16-1$ & $p B C 16$ & 1.8 & $E c o$ RI & $\mathrm{Tc}^{\mathrm{R}}$ \\
\hline pBS 161-1 & $p B C 16 / p B S 1$ & 2.5 & EcoRI, HindIII, PstI & $\mathrm{Tc}^{\mathrm{R}}$ \\
\hline$p L S 103$ & $\begin{array}{l}p L S 28 / \mathrm{RSF} \\
2124-\mathrm{B} . \mathrm{leu}\end{array}$ & 6.5 & BamHI, SmaI, HpaI, XmaI & leu \\
\hline$p L L 10$ & $p L S 103$ & 5.7 & $E c o$ RI, BamHI, BgI, XmaI & leu \\
\hline$p T L 10$ & $p L L 10$ & 9.4 & BamHI, BgII, XmaI & leu, $\operatorname{Tmp}^{\mathrm{R}}$ \\
\hline pTL 12 & $p T L 10$ & 6.4 & BamHI, $E c o \mathrm{RI}, B g I \mathrm{II}, X m a \mathrm{I}$ & leu, $\mathrm{Tmp}^{\mathrm{R}}$ \\
\hline$p A B 224$ & $p A B 124$ & 1.95 & $\begin{array}{l}\text { EcoRI, HpaI, HpaII, HhaI, } \\
\text { ThaI, CauII, BstEII }\end{array}$ & $\mathrm{Tc}^{\mathrm{K}}$ \\
\hline$p A B 524$ & $p A B 124$ & 2.3 & HpaI, HpaII, CauII, BstEII & $\mathrm{Tc}^{\mathrm{R}}$ \\
\hline
\end{tabular}

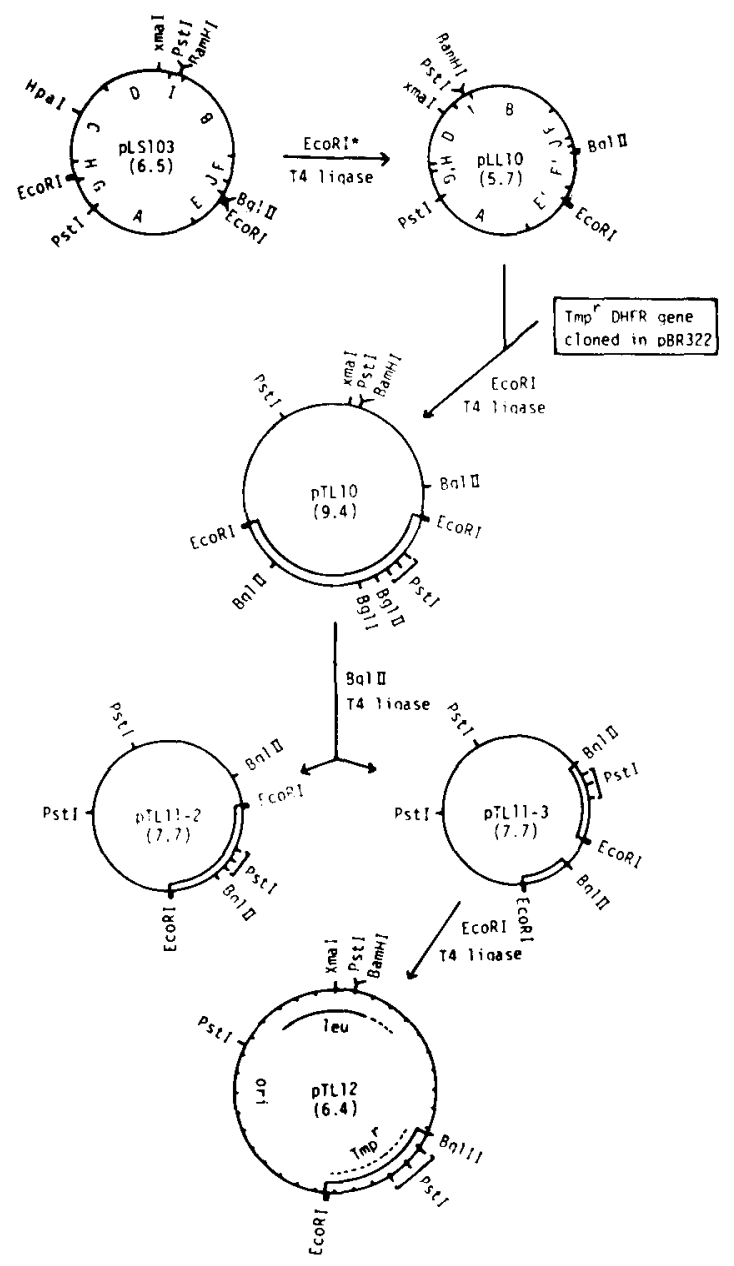

Fig. 3. Structure of plasmids $p L S 103$ to $p T L 12$. Numbers in parentheses are molecular weights. HindIII sites of $p L S 103 / p L L 10$ are shown inside the circles and these were preserved in $p T L 10$. Courtesy of T. Tanaka and N. Kawano 


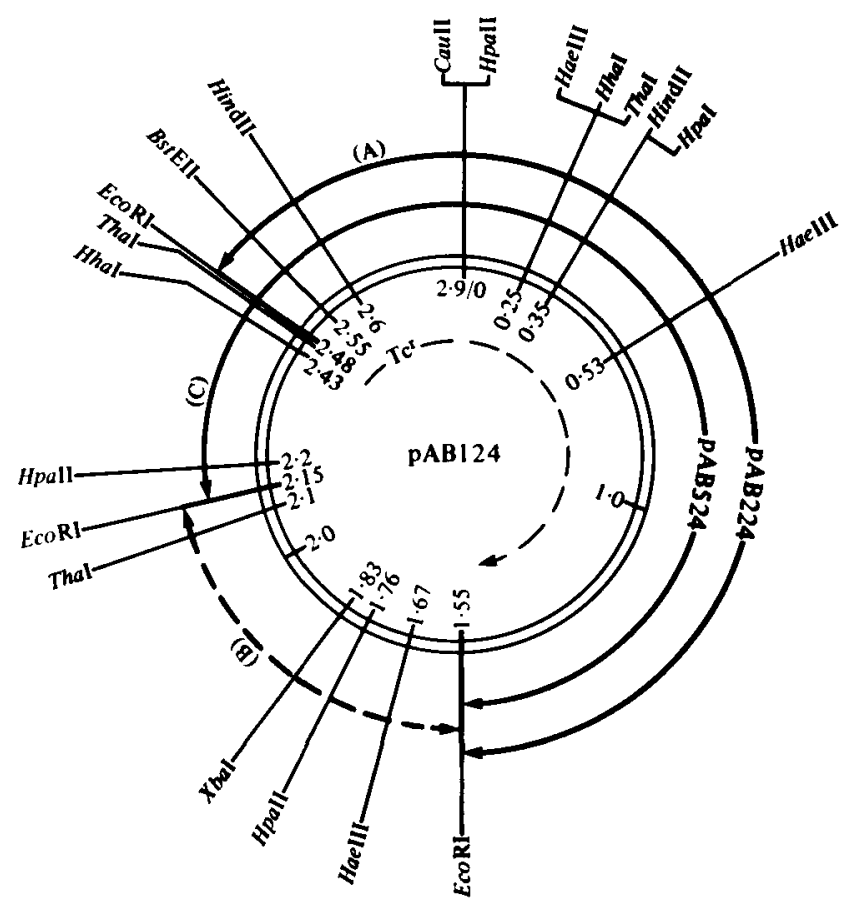

Fig. 4. Restriction endonuclease cleavage maps of $p A B 124, p A B 224$, and $p A B 524$. Courtesy of A.H.A. Bingham, C.J. Bruton, and T. Atkinson

identification of recombinant molecules by insertional inactivation. They are, therefore, of limited value as vectors for molecular cloning.

\subsection{Hybrid Vectors Capable of Replication in E. coli and B. subtilis}

The construction of hybrid vectors attempts to combine the advantages of the well-defined $E$. coli cloning systems with those of the Bacillus host.

Hybrid replicons comprising $E$. coli vector plasmids and antibiotic resistance plasmids from Staphylococcus aureus have been described by Ehrlich (this volume). We have also constructed several $S$. aureus $E$. coli hybrid plasmids of this type $(p J K 310, p J K 312$, $p J K 321, p J K 521$, and $p J K 523$ ) (Goebel et al. 1979; Kreft and Goebel, manuscript in preparation). Two of them, $p J K 310(p U B 110+p B R 325)$ (Gryczan et al. 1978; Bolivar 1978) and pJK523 ( $p C 221+p B R 322$ ) (Novick 1976; Bolivar et al. 1977), express resistance to two antibiotics in $B$. subtilis and carry single restriction sites in these markers.

In addition we have developed hybrid replicons consisting of the $E$. coli vectors pBR322 (Bolivar et al. 1977), pACYC184 (Chang and Cohen 1978) and the Bacillus plasmids $p B S 161-1$ and $p B S 1$ (Kreft et al. 1978; Goebel et al. 1979).

$p J K 3$ and $p J K 3-1$ have been constructed by ligation of HindIII-cleaved $p B R 322$ and $p B S 161-1$. From the resulting complete hybrid $p J K 3$ several duplex restriction sites have been removed by religation of PstI cleaved $p J K 3$, thus yielding $p J K 3-1$ (Fig. 5). This plas- 

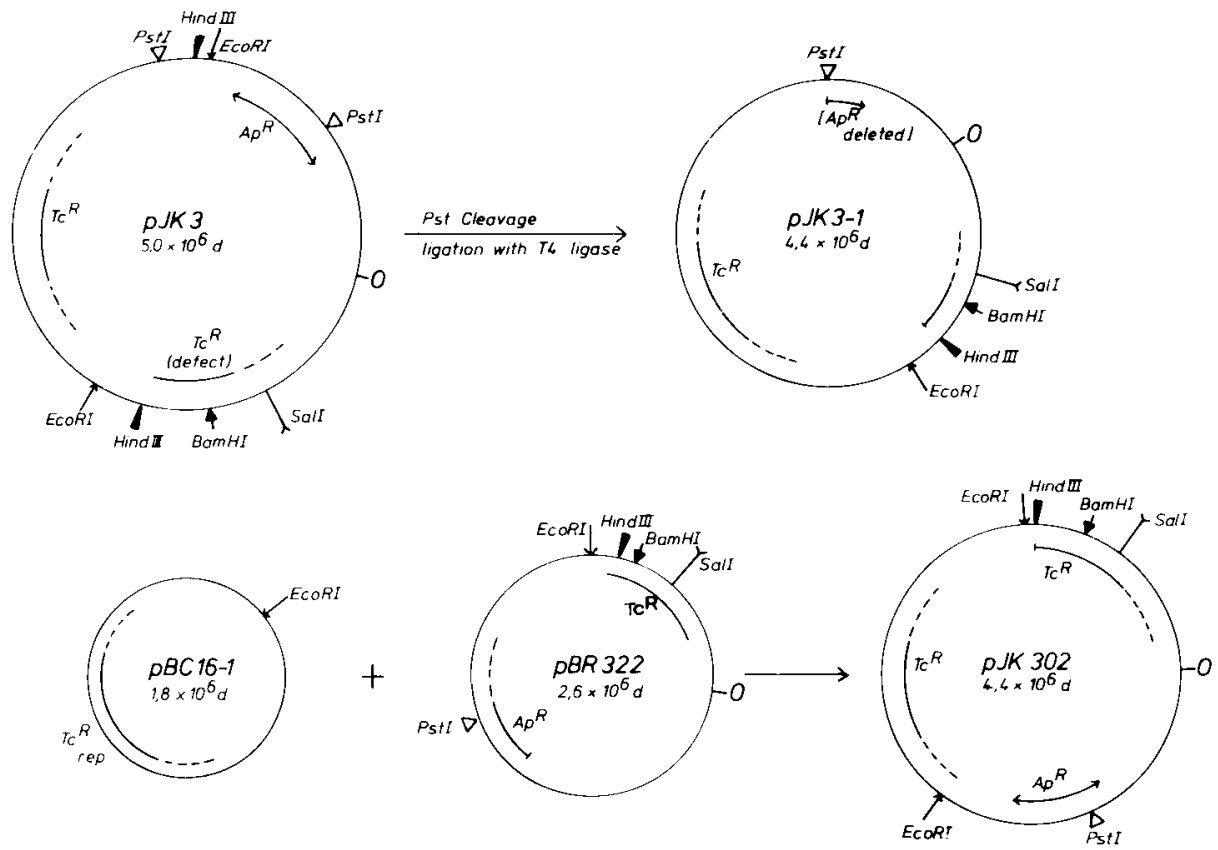

Fig. 5. Construction and restriction endonuclease cleavage maps of $p J K 3-1$ and $p J K 302$. Construction of $p J K 3$ is described in the text

mid has retained only the tetracycline resistance determinant, but has single sites for five restriction enzymes and is capable of replication in both $E$. coli and B. subtilis. After transformation of $E$. coli with a ligation mixture from HindIII-cleaved $p A C Y C 184$ and $p B S 161-$ 1, the largely deleted hybrid plasmid $p J K 201$, which carries $\mathrm{Cm}^{\mathrm{R}}$ and $\mathrm{Tc}^{\mathrm{R}}$ determinants, has been obtained (Goebel et al. 1979).

$p J K 302$ is a hybrid consisting of EcoRI cleaved $p B R 322$ and $p B C l 6-1$. It has single sites for four restriction enzymes, the $P s t \mathrm{I}$ site being situated in the $\mathrm{Ap}^{\mathrm{R}}$ gene. Cleavage with $E c o \mathrm{RI}$ of both parental plasmids does not inactivate the $\mathrm{Tc}^{\mathrm{R}}$ determinants on these; the hybrid $p J K 302$ expresses a high level (more than $100 \mathrm{\mu g} / \mathrm{ml}$ ) in both $E$. coli and $B$. subtilis (Fig. 5).

Ligation of the $E c o$ RI-cleaved plasmids $p B R 322$ and $p B S 1$ yields in $E$. col $i$ the expected complete hybrid $p J K 501$. After transformation of competent cells or protoplasts of $B$. subtilis tetracycline-resistant colonies yield numerous derivatives of $p J K 501$ which have deleted different parts of the original plasmid (Kreft and Parrisius, unpublished observations). One of those derivatives which do not undergo further rearrangements, $p J K 502$, has single restriction sites for HindIII, BamHI, SalI (in the Tc ${ }^{\mathrm{R}}$ determinant), and Pst (in the $\mathrm{Ap}^{\mathrm{R}}$ gene).

In order to convert such a bifunctional plasmid into a cosmid system, we have introduced the cos site from $p H C 79$ (Hohn and Collins 1980) into $p J K 3$, yielding $p L K 103$ (Fig. 6). But for unknown reasons all attempts to package this plasmid in vitro into lambda heads have failed so far (G. Luibrand, unpublished observations). 


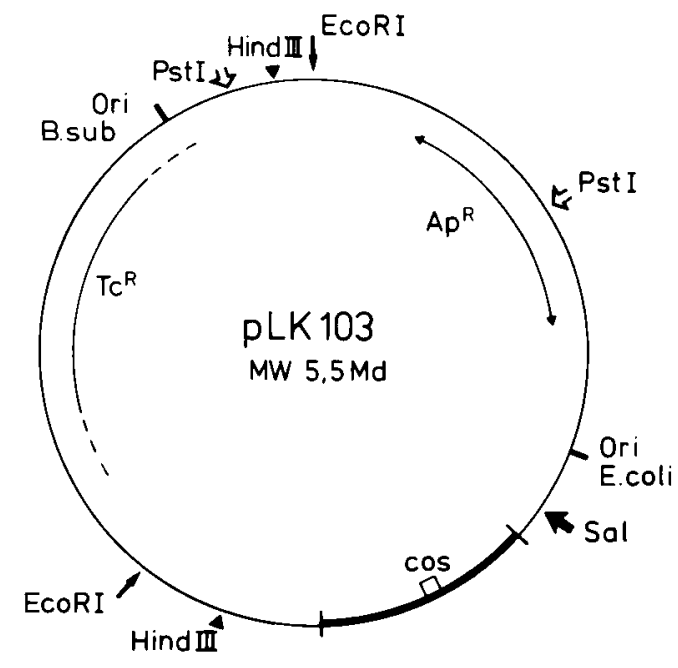

Fig. 6. Restriction endonuclease cleavage map of $p L K 103$. The thick line indicates the $B g / I \mathrm{I}$ fragment containing the cos site which has been inserted into the BamHI site of $p J K 3$

A third type of bifunctional plasmid has been obtained by ligation of EcoRI-cleaved pBS161-1 and M13mp2 phage (Gronenborn and Messing 1978) RF double-stranded DNA. The resulting hybrid molecule $p K J B 200\left(\mathrm{~mol}\right.$. wt. $7.4 \times 10^{6}$ ) replicates and expresses tetracycline resistance in both $E$. coli and $B$. subtilis, and gives rise to single-stranded DNA and phage in $E$. coli (K.J. Burger, unpublished observations). This plasmid has single restriction sites for HindIII and $P s t \mathrm{I}$ and should facilitate DNA sequencing of cloned fragments.

The plasmids $p J K 3, p J K 302, p K J 502$ and $p L K 103$ carry two antibiotic resistance markers $\left(A p^{R}\right.$ and $T c^{R}$ ), both spanning single restriction sites, thus allowing the detection of recombinant plasmids by insertional inactivation. However, due to the nonexpression of the $\mathrm{Ap}^{\mathrm{R}}$ gene from $p B R 322$ in B. subtilis (see Sect. 4) its inactivation can only be detected in $E$. coli. Nevertheless recombinant plasmids can subsequently be transformed into B. subtilis, using $\mathrm{Tc}^{\mathrm{R}}$ as a selective marker.

As will be discussed later, nonexpression and instability of cloned DNA fragments is an important problem in $B$. subtilis. It is, therefore, worthwhile to clone foreign DNA first in $E$. col $i$ and to use the "bridge" character of the described hybrid replicons to introduce the cloned genes into $B$. subtilis.

\subsection{Transformation}

Bacillus subtilis cells can be transformed by DNA either at the stage of natural competence (Spizizen 1958; Bott and Wilson 1976) or after creation of protoplasts by lysozyme treatment (Chang and Cohen 1979).

In competent cells the transformability follows the same time course for chromosomal and plasmid DNA (Contente and Dubnau 1979). Competent cells are efficiently transformed only by oligomers of plasmid DNA (Mottes et al. 1979), whereas protoplasts can be transformed with equal efficiency by monomeric or oligomeric plasmid DNA (Kreft, unpublished observations). 
It has been reported that a restriction-deficient mutant strain of $B$. subtilis can be more efficiently transformed by plasmid DNA than the restriction-proficient parental strain (Tanaka 1979). It has also been claimed that strains carrying the recE mutation transform poorly (Dubnau et al. 1980). However, in our hands the protoplast system shows no difference between the transformation rates of $B$. subtilis BR151 and BR151 recE4 or between $B$. subtilis $\mathrm{MT} 120 \mathrm{r}^{-} \mathrm{M} \mathrm{m}^{-}{ }_{\mathrm{M}}$ recE4 and $\mathrm{MT128} \mathrm{r}^{+} \mathrm{M} \mathrm{m}^{+}{ }_{\mathrm{M}}$ recE4 (Tanaka 1979). In all cases plasmids $p B S 161-1$ (a Bacillus plasmid) and $p J K 3$ (a Bacillus/E . coli hybrid plasmid) have been tested and, interestingly, no difference in transformation rate was seen regardless of whether the $p J K 3$ plasmid DNA used for transformation had been isolated from $E$. coli or from B. subtilis (Kreft, unpublished observations). Clearly the influence of restriction and/or recombination systems on the transformation rate depends upon the particular plasmid used. The transformation efficiency with competent cells or protoplasts is highest with small plasmids, but nevertheless we have been able to transform B. subtilis protoplasts with a plasmid of mol. wt. $17 \times 10^{6}$.

\subsection{Stability of Vector Plasmids}

One prerequisite for the application of a host-vector system to the molecular cloning of DNA is the stable replication of vector plasmids and recombinant molecules in the host. It seems, however, that recombinant plasmids show a remarkable tendency to undergo alterations (mainly deletions) in $B$. subtilis.

Several different mechanisms may be responsible for the phenomena observed. Plasmids can of course recombine with each other or with the chromosome if they contain homologous segments (Keggins et al. 1978; Tanaka and Sakaguchi 1978), the recE4 mutation (Dubnau and Cirigliano 1974) preventing this recombination process. Intramolecular recombination, on the other hand, can occur without involvement of the recE4 function (Tanaka 1979b). In one case it has been shown that such an event can occur in a site-specific way, giving rise to two daughter plasmids containing the entire DNA sequence of the parental plasmid (Fujii and Sakaguchi 1980). The plasmids $p B S 161$ and $p B S 162$ (see. Sect. 2.1) may have been generated by the same process, as suggested by the distribution of restriction sites on these and the parental plasmids and the fact that the sum of the molecular weights of $p B S 161$ and $p B S 162$ is roughly the same as the sum of $p B S 1$ and the large $E c o$ RI fragment of $p B C 16$.

All the hybrid plasmids described in Sect. 2.2 replicate stably in $E$. coli without detectable segregation. In $B$. subtilis the segregation rate after ten generations without selective pressure is $4 \%-65 \%$, depending on the plasmid examined. They show no deletions or rearrangements while replicating in $E$. coli, but frequently display extensive deletions when isolated from $B$. subtilis transformants.

For example, from $B$. subtilis transformed by $p J K 501$ a large variety of deleted plasmids may be obtained, the deletions affecting both parts ( $p B S 1$ and $p B R 322$ ) of the hybrid plasmid and ranging from 3.6-6.1 $\times 10^{6}$ in size. In some cases if plasmid DNA from $B$. subtilis cells transformed with this plasmid is isolated immediately after transformation, plasmids indistinguishable in size from $p J K 501$ are found, while after subcultivation large deletions are again observed. This clearly demonstrates that in this case the deletion event occurs after the uptake of the plasmid into the cell, as has also been proposed by others (Gryczan and Dubnau 1978). 
The occurrence of deletions, at least in the case of $p J K 501$, is independent of the recE function and the restriction/modification system of the recipient. Also the type of $E$. coli modification of $p J K 501$ plasmid DNA isolated from $E$. coli and used for transformation of B. subtilis had no influence on the deletion phenomenon (Kreft and Parrisius, unpublished observations).

Insertion of different foreign DNA segments into the same vector plasmid showed that not the vector itself but rather the particular combination of vector with another segment of DNA determines whether this new structure is stable in B. subtilis (see. Sect. 4).

\subsection{Clone Analysis}

The screening for recombinant plasmids is difficult in cases where no marker inactivation and no primary selection for a cloned fragment is possible. To screen for plasmids with inserts (or deletions) the use of a rapid lysis procedure is of great advantage, the method of Birnboim and Doly (1979) giving in our hands satisfactory results for B. subtilis.

It should be kept in mind, however, that due to the remarkable tendency for deletions to occur in $B$. subtilis the mere size of a plasmid isolated from transformants is not a reliable criterion in assessing its structure.

Immunologic (Broome and Gilbert 1978) and colony hybridization methods (Grunstein and Hogness 1975) can help to identify particular recombinant plasmids, but have yet to be adapted to $B$. subtilis.

For studies on the expression of cloned DNA fragments a minicell system is available for B. subtilis (Reeve et al. 1973).

\section{Use of Bacteriophage Vectors}

Several phage systems of $B$. subtilis have been well characterized (Graham et al. 1979; Cregg and Ito 1979; Mizukami et al. 1980). In particular, early work has involved the phages Ф3T and $\rho 11$ which may be termed specialized transducing phages as they carry the thymidilate synthetase gene thy $\mathrm{P3}$ (Dean et al. 1976). Kawamura et al. described in 1979 a method to construct specialized transducers of $B$. subtilis based on the phage p1l. This involved cleavage by EcoRI of DNA from $\rho 11$ and the defective phage PBSX induced from $B$. subtilis 168 . The latter phage contains only host chromosomal DNA (Okamoto et al. 1968), thus limiting the method to the cloning of homologous DNA. It has been extended by Yoneda et al. (1979) to permit the cloning into $B$. subtilis of foreign DNA for which no primary selection exists. They chose to construct a specialized transducing phage containing the $\alpha$-amylase gene(s) from B. amyloliquefaciens. Chromosomal DNA from this strain and $\Phi 3 T$ DNA were digested with $B g I I I$, mixed, and ligated. This ligated mixture was then added to a preparation of chromosomal DNA from B. subtilis RUB200, a strain prototrophic for threonine and defective in $\alpha$-amylase synthesis. This mixture was in turn incubated with $B$. subtilis RUB201, a threonine auxotroph lysogenic for $\Phi 3$ T. $t h r^{+}$transformants were selected and tested for $\alpha$-amylase production. Competent cells may take up more than one fragment of DNA (congression) so that by selecting, in this case, $t \mathrm{hr}^{+}$ transformants one effectively enriches for cells carrying foreign DNA (such selection gave a $10^{4}$-fold enrichment for $a m y^{+}$clones). Seven of $10^{5} \mathrm{thr}^{+}$transformants of RUB201 
acquired $\alpha$-amylase activity and from five of these $\Phi 3 T$ could be induced. Infection of the amy $^{-}$strain RUB200 with these phages showed a 100\% correlation between establishment of lysogeny and the amy ${ }^{+}$phenotype. Transformation and selection of amy ${ }^{+}$clones showed cotransformation with the phage specific thy $\mathrm{P} 3$ gene.

The technique has been utilized for the cloning of spo 077 (quoted in Kawamura et al. 1980) and amyE (Nomura et al. 1979) into $\rho 11$, but this phage, having a genome with mol. wt. $80 \times 10^{6}$, generates a large number of fragments after routine digestions. Ijjima et al. (1980) have, therefore, adapted the procedure to the temperate phage $\Phi 105$, which has a genome size of $26 \times 10^{6}$. Chromosomal DNA of $B$. subtilis 168 (trpC2) was prepared from phage PBSX and after EcoRI digestion ligated with $E c o$ RI digested DNA from $\Phi 105 C$. Ligated DNA was used to transform B. subtilis (trp C2 lys 3 met $\mathrm{B} 10$ ) lysogenic for $\Phi 105 C$. Selection for auxotrophic markers, subsequent mitomycin $\mathrm{C}$ induction, and transduction of the resulting lysate into $B$. subtilis (trp $\mathrm{C} 2$ lys 3 met $\mathrm{B} 10$ ) allowed isolation of $m e t \mathrm{~B}^{+}$transducing particles. While $\Phi 105 \mathrm{C} \mathrm{DNA}$ is insensitive to $\mathrm{BamHI}$, incorporation of the new met $\mathrm{B}$ fragment introduced a single site for this enzyme. This seems possible with other phages, e.g., the virulent $\Phi 1$ (Kawamura et al. 1980), which also have no BamHI site. A deletion mutant of $\Phi 1, \Phi 1 \mathrm{E} 2 \Delta 1$, has been isolated with increased cloning capacity and this has been used to clone p11 fragments which introduced BamHI and HaeIII restriction sites.

To summarize, initial bacteriophage systems have been shown to be very efficient especially in shotgun cloning of heterologous DNA. Due to the selection marker thymidilate synthetase the phage $\mathbf{\Phi 3 T}$ is particularly useful. Major limitations of the method are that by lysogenization normally only single gene copies can be introduced into recipient cells and that induction of lysogens leads to lysis, which might cause containment problems.

\section{Molecular Cloning with Plasmid Vectors}

In a strict sense the construction of vector plasmids like $p J K 3$ (Kreft et al. 1978) or $p T L 12$ (Tanaka and Kawano 1980) has already involved the cloning of either heterologous or homologous DNA. This section describes the cloning and expression of isolated genomic fragments and the expression of genetic markers on hybrid replicons.

It has been shown that, at least in certain cases, even DNA cloned in an E. colivector plasmid can transform $B$. subtilis without replication of the recombinant plasmid in the Bacillus host (see also Sect. 2.1). The thymidilate synthetase gene from B. subtilis bacteriophage $\Phi 3 \mathrm{~T}$, which has extensive homology to the chromosomal gene, can transform thy ${ }^{-}$B. subtilis to thy ${ }^{+}$when cloned in $p S C 101$ or $p M B 9$ (Ehrlich et al. 1976). On the other hand, the nonhomologous thymidilate synthetase gene from phage $\beta 22$ can only transform $t h y^{-B}$. subtilis when cloned into an $E$. coli plasmid carrying a small fragment of DNA homologous to the B. subtilis chromosome (Duncan et al. 1978; Young 1980). In this case the whole recombinant plasmid becomes integrated into the chromosome. Recently it has been shown that the thymidilate synthetase gene from $E$. coli can also transform B. subtilis when cloned into $p B R 322$ or $p M B 9$ (Rubin et al. 1980). It is not yet clear, however, if there exists sequence homology between the cloned gene and the $B$. subtilis chromosome.

Most of the hybrid plasmids described in Sect. 2.2 carry more than one antibiotic 
Table 3. Expression of antibiotic resistance markers on hybrid replicons in E. coli and B. subtilis

\begin{tabular}{lllll}
\hline Plasmid & Marker & Source & \multicolumn{2}{l}{ Expression in } \\
\cline { 3 - 5 } & & & E. coli & B. subtilis \\
\hline \multirow{2}{*}{$p J K 3$} & $\mathrm{Ap}^{\mathrm{R}}$ & $p B R 322$ & + & - \\
& $\mathrm{Tc}^{\mathrm{R}}$ & $p B S 161-1$ & + & + \\
pJK 201 & $\mathrm{Cm}^{\mathrm{R}}$ & $p A C Y C 184$ & + & - \\
& $\mathrm{Tc}^{\mathrm{R}}$ & $p B S 161-1$ & + & + \\
$p J K 502$ & $\mathrm{Ap}^{\mathrm{R}}$ & $p B R 322$ & + & + \\
& $\mathrm{Tc}^{\mathrm{R}}$ & $p B R 322$ & + & + \\
\hline
\end{tabular}

resistance marker. Transformation studies have revealed, however, that these markers are not always expressed in both host bacteria, as is shown in Table 3.

Hybridization of in vivo radioactively labeled RNA from $B$. subtilis carrying $p J K 3$ or pJK201 (Goebe ${ }^{\prime}$ et al. 1979; Kreft et al., manuscript in preparation) to restriction fragments of these plasmids showed that the nonexpression of the $E$. coli $\mathrm{Ap}^{\mathrm{R}}$ ( $\beta$-lactamase) and the $\mathrm{Cm}^{\mathrm{R}}$ (chloramphenicol acetyl transferase) genes in $B$. subtilis is due to a transcriptional block. That no structural rearrangement in the DNA sequence of these genes is responsible for this lack of expression was shown following successful retransformation of $E$. co$l i$ with plasmid DNA isolated from B. subtilis (Goebel et al. 1979).

The tetracycline resistance determinant of $p B R 322$ (combined with $p B S 1$ to give $p J K 501$ ) can be expressed in $B$. subtilis. It is not, however, clear if this resistance determinant indeed originates from $E$. coli. In addition, since the $\mathrm{Tc}^{\mathrm{R}}$ determinant in $p J K 501$ is very close to the Bacillus part of the hybrid plasmid, it is possible that its transcription starts at a Bacillus promoter.

The tetracycline resistance specified by $p B C 16$ is expressed in $E$. coli, although at a reduced level (Kreft et al. 1978). The differences observed in expression of E. coli and Bacillus genes in the nonhomologous host might be explained by the promoter specificity of the RNA polymerase. In vitro studies with RNA polymerase from $B$. subtilis have shown that this enzyme preferentially binds to and transcribes from Bacillus promoters ( Williamson and Doi 1978; Lee et al. 1980) in contrast to E. coli RNA polymerase, which transcribes nonhomologous genes quite efficiently (Davison et al. 1979).

It has been shown by Ehrlich (1977) that plasmids from S. aureus can express $\mathrm{Cm}^{\mathrm{R}}$ or $\mathrm{Tc}^{\mathrm{R}}$ in B. subtilis. In order to see whether the $\beta$-lactamase (E.C. 3.5.2.6.) mediating $\mathrm{Ap}^{\mathrm{R}}$ in $S$. aureus can also be expressed in B. subtilis we recloned an EcoRI fragment, containing the $\beta$-lactamase gene (from $p S C 122$, Timmis et al. 1975), into $p J K 3-1 . \mathrm{Ap}^{\mathrm{R}} / \mathrm{Tc}^{\mathrm{R}}$ transformants of $E$. coli contained the recombinant plasmid $p J K 401$ and restriction analysis showed that deletions had occurred in both the vector and in the fragment originating from S. aureus. B. subtilis can be transformed to $\mathrm{Tc}^{\mathrm{R}}$ with $p J K 401$ and the plasmid replicates stably in this host. $\mathrm{Ap}^{\mathrm{R}}$ is not expressed nor can $\beta$-lactamase activity be detected intracellularly (Kreft, unpublished observations). It remains to be seen whether this nonexpression in $B$. subtilis is due to the removal of regulatory DNA sequences by the observed deletion.

Shotgun cloning experiments in B. subtilis seem, from the experience of ourselves and several others, to be rather difficult to perform. The main problem, in addition to 
nonexpression of heterologous genes, seems to be the difficulty, seen particularly in shotgun experiments, in cloning large fragments of DNA. In one case it was shown that the mean size (mol. wt. $1 \times 10^{6}$ ) of DNA inserts found in recombinant plasmids is only one-third of the mean size of the fragments in the EcoRI or HindIII digested donor DNA (Michel et al. 1980). It is not yet clear if this phenomenon reflects a preferential transformation of recombinant plasmids with small inserts or is due to posttransformational deletions.

A similar experience has been made during attempts to clone the sporulation gene spoOF from B. subtilis 60015. EcoRI digested DNA from this strain, enriched 870-fold for the spoOF gene, was ligated to $E c o \mathrm{RI}$ linearized plasmid $p B S 161-1$, and the asporogenous mutant $B$. subtilis strain JH756b was transformed with the ligated mixture. One of the tetracycline-resistant transformants contained $p B S 161-1$ with a small insert of DNA, but this plasmid could not complement the sporulation deficiency (Rhaese et al. 1979).

Several methods have been proposed to circumvent these difficulties (Dubnau et al. 1980 ). In order to examine the usefulness of cloning first into $E$. coli as an intermediate host we have tried to study the stability and expression in B. subtilis of DNA fragments cloned in $E$. coli following their recloning into $B$. subtilis $/ E$. coli hybrid vectors.

We have recloned the $E$. coli pho $A$ gene encoding the periplasmic enzyme alkaline phosphatase (E.C. 3.1.3.1) which is located on a HindIII/BamHI fragment (mol. wt. $3 \times 10^{6}$ ) of $p S B 53$ ( W. Boidol and $G$. Siewert, manuscript in preparation) into $p J K 3-1$. The resulting plasmid $p J K 353$ can transform $E$. coli $\mathrm{SB} 44$ (phoA) to pho ${ }^{+}$but not $B$. subtilis GSY172 (phoP8 argA11) (Le Hégarat and Anagnostopoulos 1973). All the $\mathrm{Tc}^{\mathrm{R}}$ B. subtilis transformants tested contain a derivative of $p J K 353$ with a large deletion of mol. wt. $5.6 \times$ $10^{6}$.

This deletion affects the phoA gene thereby precluding until now study of its expression in B. subtilis. Nevertheless, further investigations should indicate how Bacilli, which transport extracellular enzymes to the external medium (for a review see Priest 1977), transport $E$. coli enzymes which are normally periplasmic, i.e., are only carried through the inner (cytoplasmic) membrane.

Also using $p J K 3-1$ as a vector the pen gene of $B$. licheniformis, specifying $\beta$-lactamase, has been cloned in $B$. subtilis. Either the gene already cloned into a $\lambda$ vector (Brammar et al. 1980) or cloned during a shotgun experiment into phage fd was used as a DNA source. The EcoRI fragment of mol. wt. $2.8 \times 10^{6}$ carrying the $\beta$-lactamase genes was inserted into pJK3-1 in both orientations and in both cases gave $\mathrm{Tc}^{\mathrm{R}} / \mathrm{Ap}^{\mathrm{R}}$ transformants in $E$. coli and B. subtilis. The recombinant plasmid containing the fragment from $\lambda$ pen was rather stably maintained in B. subtilis, whereas the plasmid with the fragment from the shotgun cloning became deleted after a few generations (Neugebauer 1980 ). The expression of the $\beta$-lactamase was dependent upon the particular recombinant plasmid and the recipient strain. In $B$. subtilis SB202 only about $1 \%$ of the activity found in the donor strain of $B$. licheniformis was expressed. In $B$. subtilis $\mathrm{BD} 170$ the expression of $\beta$-lactamase from the fragment obtained by shotgun cloning was very good. With the fragment from lambda pen only $10 \%-30 \%$ of this activity was seen in BD170 (Sprengel, personal communication).

A similar cloning experiment has recently been reported (Gray and Chang 1981) using a bifunctional replicon from $E$. coli and $S$. aureus as a vector. The $B$. licheniformis $\beta$ lactamase was efficiently expressed and processed in both $E$. coli and B. subtilis BD 224 and secreted into the medium by the Bacillus host.

Recombinant plasmids containing genes for exoproteins like $\beta$-lactamase may be 
very useful as exportation vectors facilitating the secretion of other proteins, the genes for which being fused to the essential parts of the exoenzyme gene.

It has been shown in several cases that genes from the yeast $S$. cerevisiae can be expressed after cloning and introduction into $E$. coli and can complement auxotrophic mutations (Struhl et al. 1976; Ratzkin and Carbon 1977). A small HindIII fragment of mol. wt. $2 \times 10^{6}$ containing the arg4 gene of $S$. cerevisiae (Clarke and Carbon 1978) has been recloned from $p Y e$ (arg4) 402-11 into $p J K 3-1$ and the resulting recombinant plasmid $p J K 3-1$ (arg4) transforms E. coli JA228 argH to arg $^{+}$, but not B. subtilis GSY172 phoP8 argA 11. In addition, no argininosuccinate lyase (E.C. 4.3.2.1.) activity can be detected in the cells (Kreft, unpublished observations). The recombinant plasmid is stable in B. subtilis and plasmid DNA isolated from this host can retransform $E$. coli argH to arg $^{+}$. It has been demonstrated that the HindIII fragment containing the arg4 gene carries a promoter which functions in $E$. coli (Clarke and Carbon 1978) but which from preliminary studies seems to allow no transcription in $B$. subtilis.

\section{Conclusions}

Compared to the very sophisticated vectors and recombinant DNA techniques available in $E$. coli, the application of this methodology to $B$. subtilis is still in its infancy. However, the rapidly increasing amount of research in this field may soon allow exploitation of the particular advantages of $B$. subtilis as a host for cloned DNA.

These include (i) nonpathogenicity, (ii) lack of endotoxin, (iii) direct selection of cloned genes which are specific for this species e.g., genes encoding for sporulation and exoenzymes, the latter being of additional interest in the development of "export vectors", and (iv) the possibility of using the transformability of competent cells of B. subtilis by homologous chromosomal DNA for the "scaffolding technique" (Young 1980) and also for the enrichment of specific markers in DNA samples prior to cloning.

Until now the use of indigenous bacteriophage systems and of $E$. coli as an intermediate host for $E$. coli/Bacillus hybrid plasmid vectors has proved most promising in shotgun cloning, but large problems remain, particularly the nonexpression of heterologous genes and the instability of cloned DNA fragments, which clearly are much more important in this host than in $E$. coli.

Further developments which seem particularly necessary to achieve successful application of the recombinant DNA technique in Bacillus are (i) host mutants which allow more stable maintenance of cloned DNA and (ii) vectors which can express heterologous genes regardless of the presence of suitable transcription and translation signals on the cloned fragment.

An in vitro packaging system into bacteriophage heads, comparable to the cosmid system of $E$. coli, should increase the cloning capacity of plasmid vectors.

For the practical application of the recombinant DNA technique in $B$. subtilis to the microbial production of commercially and medically important compounds, as well as the study of regulation processes in this bacterium, vectors with variable copy number or inducible expression of cloned genes will be of great importance.

Acknowledgements. The authors wish to thank $D r . W$. Goebel for initiating this work, critical reading of the manuscript and for helpful suggestions. Drs. K.J. Burger, G. Luibrand, K. Neugebauer, G. 
Siewert, and $R$. Sprengel are thanked for communicating some of their unpublished results and $D r$. H.J. Rhaese for sending reprints of his work. We are grateful to Drs. T. Atkinson, A.H.A. Bingham, C.J. Bruton, N. Kawano, K. Sakaguchi, and T. Tanaka, Elsevier/North-Holland Biomedical Press, the Society for General Microbiology, and Springer-Verlag for the permission to reproduce figures and to Mrs. E. Appel for typing the manuscript. This work was supported by the Deutsche Forschungsgemeinschaft (SFB 105 A 12).

\section{References}

Bernhard K, Schrempf H, Goebel W (1978) Bacteriocin and antibiotic resistance plasmids in Bacillus cereus and Bacillus subtilis. J Bact 133:897-903

Bingham AHA, Bruton CJ, Atkinson T (1979) Isolation and partial characterization of four plasmids from antibiotic-resistant thermophilic bacilli. J Gen Microbiol 114:401-408

Bingham AHA, Bruton CJ, Atkinson T (1980) Characterization of Bacillus stearothermophilus plasmid pAB124 and construction of deletion variants. J Gen Microbiol 119:109-115

Birnboim HC, Doly J (1979) A rapid alkaline extraction procedure for screening recombinant plasmid DNA. Nucleic Acids Res 7:1513-1523

Bolivar F (1978) Construction and characterization of new cloning vehicles. III. Derivatives of plasmid pBR322 carrying unique EcoRI sites for selection of EcoRI generated recombinant molecules. Gene 4:121-136

Bolivar F, Rodriguez RL, Greene PJ, Betlach MC, Heyneker HL, Boyer HW, Crosa JH, Falkow S (1977) Construction and characterization of new cloning vehicles. II. A multipurpose cloning system. Gene 2:95-113

Bott KF, Wilson GA (1967) Development of competence in the Bacillus subtilis transformation system. J Bacteriol 94:562-570

Brammar WJ, Muir S, McMorris A (1980) Molecular cloning of the gene for the $\beta$-lactamase of Bacillus licheniformis and its expression in Escherichia coli. MGG 178:217-224

Broome S, Gilbert W (1978) Immunological screening method to defect specific translation products. Proc Natl Acad Sci USA 75:2746-2749

Carlton BC, Smith MPW (1974) Size distribution of the closed circular deoxyribonucleic acid molecules of Bacillus megaterium. Sedimentation velocity and electron microscope measurements. J Bacteriol 117:1201-1209

Chang ACY, Cohen SN (1978) Construction and characterization of amplifiable multicopy DNA cloning vehicles derived from the P15A cryptic miniplasmid. J Bacteriol 134:1141-1156

Chang S, Cohen SN (1979) High frequency transformation of Bacillus subtilis protoplasts by plasmid DNA. MGG 168:111-115

Clarke L, Carbon J (1978) Functional expression of cloned yeast DNA in Escherichia coli: Specific complementation of argininosuccinate lyase $(\operatorname{argH})$ mutations. J Mol Biol 120:517-532

Contente S, Dubnau D (1979) Characterization of plasmid transformation in Bacillus subtilis: kinetic properties and the effect of DNA conformation. MGG 167:251-258

Cregg JM, Ito J (1979) A physical map of the genome of temperate phage $\Phi$ 3T. Gene 6:199-219

Davison BL, Leighton T, Rabinowitz JC (1979) Purification of Bacillus subtilis RNA polymerase with heparinagarose. In vitro transcription of $\Phi 29$ DNA. J Biol Chem 254:9220-9226

Dean DH, Orego JC, Hutchinson KW, Halvorson HO (1976) A new temperate phage for Bacillus subtilis, $\rho 11$. J Virol 20:509-519

Dubnau D, Cirigliano C (1974) Genetic characterization of recombination-deficient mutants of Bacillus subtilis. J Bacteriol 117:488-493

Dubnau D, Gryczan T, Contente S, Shivakumar AG (1980) Molecular cloning in Bacillus subtilis. In: Setlow JK, Hollaender A (eds) Genetic engineering, vol 2. Plenum Press, New York, pp 115-131

Duncan CH, Wilson GA, Young FE (1978) Mechanism of integrating foreign DNA during transformation of Bacillus subtilis. Proc Natl Acad Sci USA 75:3664-3668 
Ehrlich SD (1977) Replication and expression of plasmids from Staphylococcus aureus in Bacillus subtilis. Proc Natl Acad Sci USA 74:1680-1682

Ehrlich SD, Bursztyn-Pettegrew H, Stroynowski I, Lederberg J (1976) Expression of the thymidilate sythetase gene of the Bacillus subtilis bacteriophage phi-3-T in Escherichia coli. Proc Natl Acad Sci USA 73:4145-4149

Fujii M, Sakaguchi K (1980) A site-specific recE4-independent intramolecular recombination between Bacillus subtilis and Staphylococcus aureus DNAs in hybrid plasmids. Gene 12:95-102

Goebel W, Kreft J, Burger KJ (1979) Molecular cloning in Bacillus subtilis. In: Timmis KN, Pühler A, (eds) Plasmids of medical, environmental and commercial importance. Elsevier/ North-Holland Biomedical Press, Amsterdam, pp 471-480

Graham S, Yoneda Y, Young FE (1979) Isolation and characterization of viable deletion mutants of Bacillus subtilis bacteriophage SP02. Gene 7:69-77

Gray O, Chang S (1981) Molecular cloning and expression of Bacillus licheniformis $\beta$-lactamase gene in Escherichia coli and Bacillus subtilis. J Bacteriol 145:422-428

Gronenborn B, Messing J (1978) Methylation of single-stranded DNA in vitro introduces new restriction endonuclease cleavage sites. Nature 272:375-377

Grunstein M, Hogness DS (1975) Colony hybridization: A method for the isolation of cloned DNAs that contain a specific gene. Proc Natl Acad Sci USA 72:3961-3965

Gryczan TJ, Dubnau D (1978) Construction and properties of chimeric plasmids in Bacillus subtilis. Proc Natl Acad Sci USA 75:1428-1432

Henner DJ, Hoch JA (1980) The Bacillus subtilis chromosome. Microbiol Rev. 44:57-82

Hohn B. Collins J (1980) A small cosmid for efficient cloning of large DNA fragments. Gene 11:291-298

Iijima T, Kawamura F, Saito H, Ikeda Y (1980) A specialized transducing phage constructed from Bacillus subtilis phage $\Phi 105$. Gene 9:115-126

Kawamura F, Saito H, Ikeda Y (1979) A method for construction of spezialized transducing phage p11 of Bacillus subtilis. Gene 5:87-91

Kawamura F, Saito H, Ikeda Y (1980) Bacteriophage $\Phi 1$ as a gene cloning vector in Bacillus subtilis. MGG 180:259-266

Keggins KM, Duvall EJ, Lovett PS (1978) Recombination between compatible plasmids containing homologous segments requires the Bacillus subtilis rec $\mathrm{E} 4$ gene product. J Bacteriol 134:514520

Kreft J, Bernhard K, Goebel W (1978) Recombinant plasmids capable of replication in B. subtilis and $E$. coli. MGG 162:59-67

Lee G, Talkington C, Pero J (1980) Nucleotide sequence of a promoter recognized by Bacillus subtilis RNA polymerase. M G G 180:57-65

Le Hégarat J-C, Anagnostopoulos C (1973) Purification, subunit structure and properties of two repressible phosphohydrolases of Bacillus subtilis. Eur J Biochem 39:525-539

Lovett PS, Bramucci MG (1975) Plasmid deoxyribonucleic acid in Bacillus subtilis and Bacillus pumilus. J Bacteriol 124:484-490

Lovett PS, Duvall EJ, Keggins KM(1976) Bacillus pumilus plasmid pPL10: properties and insertion into Bacillus subtilis 168 by transformation. J Bacteriol 127:817-828

Michel B, Palla E, Niaudet B, Ehrlich SD (1980) DNA cloning in Bacillus subtilis. Ill. Efficiency of random-segment cloning and insertional inactivation vectors. Gene 12:147-154

Mizukami T, Kawamura F, Takahashi H, Saito H (1980) A physical map of the genome of the Bacillus subtilis temperate phage p11. Gene 11:157-162

Mottes M, Grandi G, Sgaramella V, Canosi U, Morelli G, Trautner TA (1979) Different specific activities of the monomeric and oligomeric forms of plasmid DNA in transformation of B. subtilis and E. coli. MGG 174:281-286

Nagahari K, Sakaguchi K (1978) Clining of Bacillus subtilis leucine A, B and C genes with Escherichia coli plasmids and expression of the leuC gene in E. coli. MGG 158:263-270

Neugebauer K (1980) Untersuchungen zur Konstruktion von Einzelstrangvektoren in $E$. coli und eines Exportvektors für B. subtilis. Ph. D. thesis, Heidelberg

Nomura S, Yamane K, Masuda T, Kawamura F, Mizukami T, Saito H, Takatuki M, Tamura G, Maruo B (1979) Construction of transducing phage $\rho 11$ containing $\alpha$-amylase structural gene of Bacillus subtilis. Agric Biol Chem 43:2637-2638 
Novick R (1976) Plasmid-protein relaxation complexes in Staphylococcus aureus. J Bacteriol 127:1177-1187

Okamoto K, Mudd JA, Mangan J, Huang WM, Subbaiah TV, Marmur J (1968) Properties of the defective phage of Bacillus subtilis. J Mol Biol 34:413-428

Priest FG (1977) Extracellular enzyme synthesis in the genus Bacillus. Bacteriol Rev 41:711-753

Ratzkin B, Carbon J (1977) Functional expression of cloned yeast DNA in E. coli. Proc Natl Acad Sci USA 74:487-491

Reeve JN, Mendelson NH, Coyne SI, Hallock LL, Cole RM (1973) Minicells of Bacillus subtilis. J Bacteriol 114:860-873

Rhaese HJ, Groscurth R, Vetter R, Gilbert H (1979) Regulation of sporulation by highly phosphorylated nucleotides in Bacillus subtilis. In: Koch G, Richter D (eds) Regulation of macromolecular synthesis by low molecular weight mediators. Academic Press, New York, pp 145-159

Rostas K, Dobritsa SV, Dobritsa AP, Koncz C, Alfödi L (1980) Megacinogenic plasmid from Bacillus megaterium 216. MGG 180:323-329

Rubin EM, Wilson GA, Young FE (1980) Expression of thymidylate synthetase activity in Bacillus subtilis upon integration of a cloned gene from Escherichia coli. Gene 10:227-235

Spizizen J (1958) Transformation of biochemically deficient strains of Bacillus subtilis by deoxyribonucleate. Proc Natl Acad Sci USA 44:1072-1078

Struhl K, Cameron JR, Davis RW (1976) Functional genetic expression of eukaryotic DNA in Escherichia coli. Proc Natl Acad Sci USA 73: 1471-1475

Tanaka T, Koshikawa T (1977) Isolation and characterization of four types of plasmids from Bacillus subtilis (natto). J Bacteriol 131:699-701

Tanaka T, Sakaguchi K (1978) Construction of a recombinant plasmid composed of B. subtilis leucine genes and a B. subtilis (natto) plasmid: its use as cloning vehicle in B. subtilis 168 . MGG $165: 269-276$

Tanaka T (1979a) Restriction of plasmid-mediated transformation in Bacillus subtilis 168. MGG $175: 235-237$

Tanaka (1979b) recE4-independent recombination between homologous deoxyribonucleic acid segments of Bacillus subtilis plasmids. J Bacteriol 139:775-782

Tanaka T, Kawano N (1980) Cloning vehicles for the homologous Bacillus subtilis host-vector system. Gene 10:131-136

Timmis K, Cabello F, Cohen SN (1975) Cloning, isolation and characterization of replication regions of complex plasmid genomes. Proc Natl Acad Sci USA 72:2242-2246

Uozumi T, Ozaki A, Beppu T, Arima K (1980) New cryptic plasmid of Bacillus subtilis and restriction analysis of other plasmids found by general screening. J Bacteriol 142:315-318

Williamson VM, Doi RH (1978) Delta factor can displace sigma factor from Bacillus subtilis RNA polymerase holoenzyme and regulate its initiation activity. MGG 161:135-141

Yoneda Y, Scott G, Young FE (1979) Cloning of a foreign gene coding for $\alpha$-amylase in Bacillus subtilis. Biochem Biophys Res Commun 91:1556-1564

Young FE (1980) Impact of cloning in Bacillus subtilis on fundamental and industrial microbiology. J Gen Microbiol 119:1-15 